to provide quantity and quality of grass and home produced feeding stuffs, including home grown grain and legumes, milk production would be most benefitted not by the availability of middlings but by the importation of a reasonable quantity of maize together with some really high quality protein cake, or oil seeds to provide such cake. Given these and her present quantity of bran, the peace time cow could get on quite comfortably without any wheat middlings at all.

The cow is, fortunately, not a serious competitor with the human being for food. The peace time dairy farmer, if he had bran and the imported concentrates just mentioned, would be quite happy to leave on the one hand the human consumer who wishes for a more nutritious loaf than that provided by 73 per cent. extraction flour, and on the other the votaries of the pig and hen, to thrash out between them what the rate of flour extraction should be. I am sure Mr. Halnan will explain that the pig and the hen are concerned in a way that the cow is not in having a substantial supply of middlings fairly rich in B vitamins.

I am much indebted to my colleague, Mr. A. S. Foot, for his help with certain aspects of this short paper.

\title{
ReFERENCES
}

Jordan, W. H., Hart, E. B. and Patten, A. J. (1906). Tech. Bull. N.Y. St. agric. Exp. Sta. no. 1.

Kent-Jones, D. W. (1939). Modern Cereal Chemistry, 3rd Ed., p. 290. Liverpool : The Northern Publishing Co.

Ministry of Food. Scientific Adviser's Division (1944). Nature, Lond., 154, 788.

Woodman, H. E. and Evans, R. E. (1944). J. agric. Sci. 34, 35.

\section{Value of Wheat Offals for Pigs and Poultry}

Mr. E. T. Halnan (School of Agriculture, Cambridge)

\section{Introduction}

Wheat offals consist of a variety of products of varying compasition arising from the milling of wheat for flour. Wood and Adie (1917) showed that the finer grades of wheat offals sold in this country could be classified into three pure grades, pollards, coarse middlings and fine middlings, and three mixed grades consisting of admixtures of two or more of the three pure grades. Subsequently the Millers' Mutual Association (1933) standardized the grades of wheat offal manufactured in England and Wales into three grades, superfine weatings with a maximum fibre content of 4.5 per cent., weatings with a maximum fibre content of $\mathbf{5 . 7 5}$ per cent., and bran, whose fibre content normally exceeds $7 \cdot 5$ per cent. The amount of home milled wheat offals forms a material contribution to the supply of animal feeding stuffs, the estimated 5,000,000 tons of wheat milled in this country yielding, on the basis of a 70 per cent. extraction of flour, 650,000 tons of bran and 800,000 tons of middlings or weatings.

The main body of the wheat grain consists of an endosperm composed of starch cells with an outer layer of protein cells known as the aleurone layer. The germ or embryo is on the dorsal side of the grain, and extends vot. 4,1946 ] 
from the base to about one-third of the length of the kernel. The bran coats form an external protective covering to the germ and endosperm. In the milling of wheat for flour a mechanical separation of the various parts of the wheat grain takes place.

The flour consists principally of the starchy endosperm; the middlings or weatings comprise the major portion of the germ, some endosperm, and the finer particles of the bran coats, whereas the bran itself consists principally of the outer coverings or bran coats of the wheat kernel together with some starchy matter from the endosperm.

Owing to the custom of farmers from the earliest days of talking their wheat to the country mills for milling and taking back to the farms the wheat offals for the use of the farm animals, the value of these products for animal feeding has been established by traditional rule of thumb methods. As a result, very little experimental evidence exists in the early literature on the value of these products for stock feeding, and the need for experimental work on the subject began to be realized only with the decay of the country mills and the concentration of the milling industry in the big towns and port areas, when the millers were faced with the problem of disposal of the big stocks of wheat offals arising in the course of their trade.

\section{Value of Wheat Offals for Pigs}

In the United States, the State Experiment Stations carried out some experimental investigations on the use of wheat offals for pig feeding. Bartlett (1890) compares the feeding value of bran and middlings in conjunction with skim milk, and states that the growth obtained with middlings was double that obtained with bran. Cooke (1891) compared the value of maize meal with that of middlings when given in conjunction with skim milk, and found that maize meal gave better results than middlings in the case of young pigs. Harcourt (1891) expressed the view that wheat bran used with butter milk or skim milk was a good food for hogs, but Burkett (1899) concluded from his experiments that bran was undesirable as a food for pigs. Mairs and Doty (1910) compared middlings as a sole source of food for pigs with a mixture of maize chop and tankage, and concluded that middlings alone was not very profitable as a feeding stuff for growing and fattening pigs. The middlings ration gave better results in the early stages of the trial, but the maize chop and tankage ration gave better results later on.

In this country Lawes (1853) in his investigations on the comparative value of protein rich and earbohydrate rich feeding stuffs for the fattening of pigs, used bran as a source of fibre. The feeding trials were carried out on lots of 3 pigs which were approximately 9 to 10 months old at the commencement of the trials, the foods used being bean meal, lentil meal, maize meal and bran in varying combinations. Each trial lasted for 8 weeks. In these trials he established the beneficial effect of bran when given in small amount with other foods, and its detrimental effect when given in large amount, as measured by the live weight increases obtained. Thus a maize meal bran ration containing about 24 per cent. of bran gave a live weight increase of $103 \mathrm{lb}$. per pig as compared with one of $74 \mathrm{lb}$. with maize only. Similarly a mixture of bran, bean meal, lentil meal and maize meal containing approximately 22 per cent. of bran gave a 
live weight increase of $122 \mathrm{lb}$. per pig as compared with one of $97 \mathrm{lb}$. with the meal mixture with bran omitted. On the other hand, a mixture of lentil meal and bean meal with about 50 per cent. of bran gave a live weight increase of just over $33 \mathrm{lb}$. per pig as compared with one of $101 \mathrm{lb}$. on the meal mixture with the bran omitted. Similarly, a mixture of bran and maize meal gave a live weight increase of $38 \mathrm{lb}$. per pig when the bran constituted 55 per cent. of the total, as compared with one of $103 \mathrm{lb}$. when the bran constituted only 24 per cent. of the total. Lawes records also one trial in which the pigs were allowed a free choice of the foods, bean meal, lentil meal, maize meal, and bran, which were supplied in separate hoppers. The live weight increase per pig was about $85 \mathrm{lb}$., and it is interesting to find that the bran consumed represented only $5 \cdot 2$ per cent. of the total food eaten. In these experiments the pigs were allowed to feed to appetite on the various rations and, from the records of food consumption, it is apparent that the detrimental effect of large amounts of bran was due to the decreased food intake brought about by its bulky and fibrous nature, thus reducing the available amount of energy provided for live weight increase. From the evidence supplied by the experiments quoted, the following deductions on the value of wheat offals for pig feeding can be drawn:

1. The inclusion of bran in small amount in pig rations consisting of maize meal and meals derived from leguminous grains has a beneficial effect, the benefit being associated with the biological value of the bran for growth purposes.

2. Wheat bran, owing to its bulky and fibrous nature, and its low available energy content, is not suited for inclusion in pig rations in large amount.

3. Middlings, as a sole source of food for pigs, is unsuitable although life may be maintained and a certain amount of growth promoted during the early stages of the pig's existence.

4. Middlings, as compared with bran, is more suitable for inclusion in pig rations in large amount, particularly in the case of young growing pigs.

\section{Value of Wheat Offals for Poultry}

The evidence as to the nutritive value for poultry of wheat offals, and as to the components of the wheat offals upon which this value depends, is more complete. From a practical point of view it has been well established that good growth in young chicks can be obtained with mashes in which wheat offals compose 40 to 60 per cent. or even more of the total mash, and a very successful mash for egg production used in county egg laying trials contained 20 per cent. bran and 40 per cent. middlings. In 1936 some experiments of a preliminary nature (Halnan, 1937) were carried out to obtain information on the possibilities of using wheat and wheat offals as growth promoting foods for young chicks. Since it was known that wheat and wheat offals contained but small amounts, if any, of vitamin $A$, no vitamin $C$ and no vitamin $D$, and inadequate amounts of calcium, these deficiencies, with the exception of that of vitamin $\mathrm{C}$, were provided for by the inclusion of cod liver oil and calcium carbonate in the experimental rations. No provision for vitamin $\mathrm{C}$ was considered necessary, since it was known that birds could be reared successfully and would breed on diets free from vitamin $\mathrm{C}$.

voL. 4,1946 ] 
When wheat was used as the sole source of food with the supplements already mentioned, it was found that some mortality occurred in the early stages of the chicks' life, and the survivors grew at a very slow rate. This rate of growth was restored to normal by the inclusion of 10 per cent. of dried milk powder at a later stage of the experiment. It was evident that wheat was deficient in certain growth factors which were present in dried milk. The first attempt to use middlings as a source of food for chicks failed, since the food, which was given dry, made a paste in the mouths of the chicks, forming hard pads below the tongue and on the roof of the mouth, thus preventing the chicks from feeding and causing early death. Poley (1938) reported similar trouble in the case of day old chicks fed on a ration containing 75 per cent. of finely ground wheat, no less than 75 per cent. of the chicks developing malformed beaks by the time they were 3 weeks old. This trouble did not arise with chicks fed on coarsely ground wheat.

Owing to the unsuitability of middlings as a sole source of food, the effect on growth of a mixture of bran and middlings in which the middlings formed 40 per cent. of the total ration, was compared with the effect of bran only, with supplements of cod liver oil and calcium carbonate included as before. In this experiment both bran, and the mixture of bran and middlings, when supplemented with cod liver oil and calcium carbonate, proved adequate for the normal growth of chicks up to the age of 8 weeks. In the early stages of the trial the chicks fed on bran made better growth than those receiving the bran and middlings but, at the later stages, the latter made better growth gains, and had nearly caught up with the bran fed chicks by the end of the trial. It was noted that the bran fed chicks were almost continually on feed, indicating that the factor limiting growth was a lack of readily available energy (Halnan, 1937). These experiments, though on a small scale, indicate the suitability of wheat offals as food for the growth of young chicks, provided that the chicks' needs for vitamin $A$, vitamin $D$ and calcium are supplied from other sources. They indicate also that the beneficial effect of including milk powder in the wheat experiment was primarily due to its providing protein of high biological value together with extra supplies of riboflavin.

The adequacy of wheat offals for supplying the vitamin B complex requirements of chicks is well established. Poley (1938) found that 20 per cent. of bran or 10 to 20 per cent. of middlings included in a diet otherwise lacking in the antineuritic factor supplied enough of it to protect chicks up to 10 weeks of age from polyneuritis. Jackson, Doherty and Malone (1943) estimated the vitamin $B_{1}$, riboflavin and nicotinic acid content of bran and middlings, the average results of their analyses, expressed in $\mu \mathrm{g}$. per $\mathrm{g}$. of food, being as follows:

\begin{tabular}{cc|c|c|c}
\hline \multicolumn{1}{c|}{ Offal } & Vitamin $B_{1}$ & Riboflavin & Nicotinic acid \\
\cline { 3 - 4 } Wheat bran &. & $6 \cdot 98$ & $2 \cdot 38$ & $232 \cdot 0$ \\
Middlings &. & 20.8 & 3.02 & $95 \cdot 0$ \\
\hline
\end{tabular}

The nutritional needs of the chick for vitamin $B_{1}$ are, therefore, amply safeguarded in diets containing 20 per cent. or more of wheat offals. 
It will further be noted that a diet consigting of bran or middlings supplies from 238 to $302 \mu \mathrm{g}$. riboflavin per $100 \mathrm{~g}$. It has been established that riboflavin is not only a factor essential for the growth of chicks, but that its presence in the diet is essential also for the prevention of a condition known as "curled toe paralysis," in which the chicks tend to rest in a squatting position with the toes in the position of a clenched fist. Bethke and Record (1942) showed that chicks needed per $100 \mathrm{~g}$. of diet, $250 \mu \mathrm{g}$. riboflavin to ensure maximum growth, and $300 \mu \mathrm{g}$. to prevent the occurrence of curled toe paralysis. The riboflavin content of middlings is sufficient to supply the riboflavin needs of the chick on a diet consisting entirely of middlings but, with bran, the amount according to Bethke and Record's findings would be insufficient to prevent curled toe paralysis though adequate for growth. . It should, however, be noted that no cases of curled toe paralysis occurred on the bran diet used in my chick experiments.

It was noticed by Briggs, Mills, Elvehjem and Hart (1942) that chicks grew slowly and developed redness and inflammation of the mouth and crop, with a white tongue tip, on rations with a nicotinie acid content not exceeding $0.3 \mathrm{mg}$. per $100 \mathrm{~g}$. of diet, whereas they grew normally with no symptoms of deficiency when the diet contained 1.5 to $2.0 \mathrm{mg}$. per $100 \mathrm{~g}$. It is apparent, therefore, that small quantities of wheat offals included in the diet will suffice to meet all the requirements of chicks for this vitamin.

There is another condition of vitamin deficiency known to occur in chicks, the characteristic symptoms being granular sticky eyelids, incrustations at the angles of the mandibles, and thickened fissured skin on the bottoms of the feet (Bauernfeind, Norris and Heuser, 1942). This condition, known as dermatitis, is due to deficiency of pantothenic acid. Bauernfeind et al. (1942) have estimated the daily pantothenic acid requirements of chicks per $100 \mathrm{~g}$. of diet to be 500 to $550 \mu \mathrm{g}$. for maximum growth, and $600 \mu \mathrm{g}$. for the prevention of this dermatitis. Later estimates by Jukes and McElroy (1943) place the pantothenic acid requirements of chicks at $1000 \mu \mathrm{g}$. per $100 \mathrm{~g}$. of diet. Bauernfeind and his co-workers found that bran contained $25 \cdot 7 \mu \mathrm{g}$. pantothenic acid per g. and middlings $15 \cdot 6 \mu \mathrm{g}$. per g. A diet containing 20 per cent. bran or 40 per cent. middlings would supply the pantothenic acid requirements at the lower level quoted, but double these amounts of wheat offals would be needed to satisfy the needs of chicks at the higher level given.

The mineral content of wheat offals is important because of the supply of manganese. This trace element is not only essential for the growth of animals, but is important also for the chick as a preventive of the condition known as perosis (Gallup and Norris, 1939), which is characterized by swelling of the hock joint, bowing of the leg bones, and displacement of the Achilles tendon. Perosis is rare in this country, but is prevalent in battery reared chicks in the United States. Gallup and Norris (1939) found that 50 parts of manganese per million parts of diet was enough to effect a cure. Skinner and Peterson (1928) found $140.4 \mathrm{mg}$. of manganese per $\mathrm{kg}$. in wheat bran, and $155.8 \mathrm{mg}$. in middlings. On this basis, a diet containing 20 per cent. of bran or middlings would supply enough manganese to prevent perosis in chicks. Since most commercial chick diets in this country contain considerably more than 20 per cent. of wheat offals, the rarity of the condition among chicks here is not surprising.

voL. 4, 1946] 
Pyridoxine (vitamin $B_{6}$ ) also has been shown to be essential for the growth of chicks. The symptoms of deficiency are slow growth, convulsions and other nervous manifestations. Briggs, Mills, Hegsted, Elvehjem and Hart (1942) have estimated the pyridoxine requirements of chicks to be 275 to $300 \mu \mathrm{g}$. per $100 \mathrm{~g}$. diet. I have been unable to find any references to the pyridoxine content of bran or middlings, but Teply, Strong and Elvehjem (1942) give values per g. for wheat of $4.6 \mu \mathrm{g}$., for wheat germ of $9 \cdot 6 \mu \mathrm{g}$., and for patent flour of $2 \cdot 2 \mu \mathrm{g}$. From the low value for flour it is apparent that pyridoxine is concentrated in the coarser milling fractions, so that it can reasonably be concluded that the values for bran and middlings are higher than $4 \cdot 6 \mu \mathrm{g}$. per $\mathrm{g}$. On this assumption, it can be concluded that diets containing 40 to 60 per cent. of wheat offals will supply adequate amounts of pyridoxine for the normal requirements of the chick.

In conclusion, a few brief remarks may be added on the extent to which wheat offals serve as a source of energy to the fowl. From considerations of the digestibility of the organic matter of wheat bran (Halnan, 1937) when given to various classes of livestock, it is apparent that fowls are unable to utilize the nutrients of bran to the same extent as other farm animals, and that bran should preferably be given to ruminants such as sheep and cattle in preference to fowls, or to pigs which utilize the nutrients of bran almost as well as sheep. In a later communication (Halnan, 1944), the superior power of the rabbit to utilize the energy of bran is elearly shown, $1 \mathrm{~kg}$. of bran yielding 2522 Calories for the rabbit, as compared with 1637 Calories for the fowl. The varying extent to which the different grades of wheat offals yield energy for the fowl will be apparent on reference to Table 1. The first three estimates are based on determinations of digestibility (Halnan, 1937); the last three were determined

TABLE 1

Metabolizable Energy for the Fowl of Dimfeirent Grades of Wheat OfFals

\begin{tabular}{|c|c|c|c|}
\hline Type of offal & $\begin{array}{l}\text { Fibre } \\
\text { content, } \\
\text { per cent. }\end{array}$ & $\begin{array}{l}\text { Metabolizable } \\
\text { energy, } \\
\text { Calories per kg. } \\
\text { dry matter }\end{array}$ & Method of measurement \\
\hline $\begin{array}{l}\text { Broad bran } \\
\text { Pollards } \\
\text { Fine middlings }\end{array}$ & $\begin{array}{r}10 \cdot 30 \\
6 \cdot 14 \\
1 \cdot 92\end{array}$ & $\begin{array}{l}1641 \\
2656 \\
3506\end{array}$ & $\begin{array}{l}\text { Calculation of digestible } \\
\text { nutrients from results of } \\
\text { digestibility determination } \\
\text { (Halnan, 1937) }\end{array}$ \\
\hline $\begin{array}{l}\text { Fine bran, } 1942 \\
\text { Coarse bran, } 1942\end{array}$ & $\begin{array}{l}8 \cdot 06 \\
9 \cdot 93 \\
9 \cdot 91\end{array}$ & $\begin{array}{l}2336 \\
1720 \\
1881\end{array}$ & $\begin{array}{l}\text { Direct bomb calorimetry on } \\
\text { food and excreta (Halnan, } \\
1944 \text { ) }\end{array}$ \\
\hline
\end{tabular}

directly by bomb calorimetry (Halnan, 1944). These figures clearly reflect the effect of the fibre content of the wheat offals on their value as sources of energy to the fowl, and indicate the desirability for poultry feeding of utilizing the finer grades of wheat offal in preference to the bran which should be used only in moderate amount. 


\section{Summary}

1. Wheat bran, in small amount, is useful as an ingredient of pig and poultry rations, but its use in large amount is contra-indicated, particularly in fattening rations.

2. Wheat offals are useful ingredients of pig and poultry rations, particularly as source of the members of the vitamin $B$ complex, vitamin $B_{1}$, riboflavin, nicotinic acid, and pyridoxine.

3. As source of energy for pigs and poultry, the finer wheat offals such as middlings or weatings, are preferable to the coarser ones such as pollards and bran.

4. The manganese content of wheat offals renders these products of value as a source of this trace element in pig and poultry rations.

\section{References}

Bartlett, J. M. (1890). Rep. Me agric. Exp. Sta. 1889.

Bauernfeind, J. C., Norris, L. C. and Heuser, G. F. (1942). Poult. Sci. 21, 142.

Bethke, R. M. and Record, P. R. (1942). Poult. Sci. 21, 147.

Briggs, G. M. (Jr.), Mills, R. C., Elvehjem, C. A. and Hart, E. B. (1942). Proc. Soc. exp. Biol., N.Y., 51, 59.

Briggs, G. M. (Jr.), Mills, R. C., Hegsted, D. M., Elvehjem, C. A. and Hart, E. B. (1942). Poult. Sci. 21, 379.

Burkett, C. W. (1899). Bull. N.H. agric. Exp. Sta. no. 66, p. 111.

Cooke, W. W. (1891). Rep. Vt agric. Exp. Sta. 1890, 4, 114.

Gallup, W. D. and Norris, L. C. (1939). Poult. Sci. 18, 76.

Halnan, E. T. (1937). J. agric. Sci. 27, 126.

Halnan, E. T. (1944). J. agric. Sci. 34, 133.

Harcourt, G. (1891). Rep. Ont. agric. Coll. 1890, 16, 206.

Jackson, S. H., Doherty; A. and Malone, V. (1943). Cereal Chem. 20, 551.

Jukes, T. H. and McElroy, L. W. (1943). Poult. Sci. 22, 438.

Lawes, J. B. (1853). J. R. agric. Soc. 14, 459.

Mairs, T. I. and Doty, S. W. (1910). Bull. Pa agric. Exp. Sta. no. 95.

Millers' Mutual Association (1933). J. Minist. Agric. 40,901.

Poley, W. E. (1938). Poult. Sci. 17, 331.

Skinner, J. T. and Peterson, W. H. (1928). J. biol. Chem. 79, 679.

Teply, L. J., Strong, F. M. and Elvehjem, C. A. (1942). J. Nutrit. 24, 167.

Wood, T. B. and Adie, R. H. (1917). J. Bd Agric. 23, 1179.

\section{General Discussion}

Professor J. A. Scott Watson (Ministry of Agriculture and Fisheries, Whitehall, London, S.W.1), opener: Since a great many different interests are concerned with questions of the supply and uses of wheat, from plant breeders and farmers to merchants and bakers as well as consumers, I propose to look at our problem from several points of view.

I have no qualifications to argue the main point that is under discussion today, the pros and cons of enrichment versus high extraction, but it happened that I had opportunities to hear American views on the subject and I may perhaps very shortly summarize these.

First of all, there is nearly complete agreement that it would be wrong to leave this whole question to be decided by the consumers themselves. The old business proverb that "the customer is always right" embodies a great lie. We know that the widespread use of low extraction flour has done harm to the generations who have lived since the invention of the roller mill. Some action then is necessary to prevent the recurrence of wholesale malnutrition among those people whose diet includes a large proportion of bread.

voL. 4, 1946] 